\title{
THE INTEGRATION OF ISLAMIC COMMERCIAL AND SOCIAL ECONOMY THROUGH PRODUCTIVE WAQF TO PROMOTE PESANTREN WELFARE
}

\author{
Ratih Winarsih ${ }^{1}$, Atika Rukminastiti Masrifah² and Khoirul Umam ${ }^{3}$ \\ ${ }^{1}$ University of Darussalam Gontor, Indonesia, ratihwinarsih2@gmail.com \\ ${ }^{2}$ University of Darussalam Gontor, Indonesia, atikamasrifah@unida.gontor.ac.id \\ ${ }^{3}$ University of Darussalam Gontor, Indonesia, khoirulumam@unida.gontor.ac.id
}

\begin{abstract}
A pesantren (Islamic boarding school) as an Islamic educational institution based on self-financing system has implemented waqf as a pillar of its development and become a potential waqf asset development. The productive waqf is considered as a key instrument for providing funds to actualizing its educational program. Since both productive waqf and pesantren emphasize sustainability, and since productive waqf can assist to support the process of education in pesantren, the study aims to investigate an integrated Islamic social and commercial economy model applicable in pesantren. This will ensure utilization of the combined resources of productive waqf and pesantren in promoting pesantren welfare. The study focuses on 263 operational chief, assatidz or teacher, musyrif, musyrifah or santri companion and santri or students in Pesantren in Java and Sumatra using. Structural Equation Modeling (SEM) adopted to examine the relationship among the five constructs i.e., productive waqf, business unit, project financing, human resource and pesantren welfare. While the reliability and validity are established, the structural relationship between the constructs reveals that the integrated model has a strong relationship with the pesantren welfare in many ways. In relation with business unit and profitable commercial activities, human resources have its significant role to assist pesantren tries its level best to realize developed productive waqf. Specifically, the result shows all five constructs have significant impact in promoting pesantren welfare, which suggests that the model as well as the instrument should be further implemented in pesantren.
\end{abstract}

Keywords: Islamic Social Economy, Islamic Commercial Economy, Productive Waqf, Pesantren Welfare, Structural Equation Modeling.

JEL Classification: C10; D78; D60; L20.

Article history:

Received : November 12, 2018

Revised : : May 15, 2019

Accepted : May 17, 2019

Available online : July 30, 2019

https://doi.org/10.21098/jimf.v5i2.1065 


\section{INTRODUCTION}

\subsection{Background}

Recently, the integration of Islamic social and commercial finance has become an interesting study due to its promotion of inclusive growth. A partial indicator of this rapid increase is disclosed by the growth in the amount of productive zakah and waqf. However, the dynamics is even more robust, as other forms of waqf instrument, i.e. cash waqf, e-waqf, sukuk linked waqf, and waqf shares, as well as its institution, have also developed in recent years.

Some cases throughout Islamic history indicate consensus that integration of Islamic social and commercial finance is an important element to attain socioeconomic welfare. The Prophet encouraged Utsman ibn 'Affan to buy a well of water and make it a waqf to provide water for all. Currently, such heritage has been extended to accommodate the need of society as waqf. To illustrate, an Indonesian Islamic charity, Dompet Dhuafa, does not charge a single person in the waqf hospital. The waqf normally covers the operating costs of that hospital. Pondok Pesantren Darussalam in Gontor, East Java, for instance, is a good example of an important role played by a waqf, where santri (students) receive free knowledge and a decent cost of living, while assatidz (teachers), musyrif, musyrifah or santri companion receive ihsan or income from the return of the invested capital of a cash waqf.

Waqf is an essential component of the history of pesantren. As the pioneer of Islamic education in Indonesia, Pesantren used waqf as the financial foundation. The pesantren impact has not only been applied in education, but also involves social, economic, religious, and culture. In this situation, pesantren became a very prospective object for productive waqf development. Moreover, the role of integration of Islamic social and commercial finance in pesantren that is useful in the development of human and intellectual capital. The kyai, assatidz or teacher, musyrif, musyrifah or santri companion, and even santri or students have an important role in the integration process.

One of the spirits of pesantren is self-sufficient. In this context, the institution does not rely on the government economic assistance or any other donation to run its educational program. To support the educational process, the institution carries out some business units, organized by the asatidz or teachers and the santri or students under direct supervision of the pesantren Kyai.

\subsection{Objective of the Study}

The integration of Islamic social and commercial economy is a fresh subject, in that the current studies on this issue are limited. The closest literature to such studies is the integration of Islamic commercial and social finance, particularly through productive waqf models. Therefore, integrating the Islamic social and commercial economy is crucially applied in pesantren for a better outcome particularly for the welfare development of the whole pesantren members and examining the most influential variables of the integration model is important to promote pesantren welfare, which is the objective of the present study. Such integration will also enhance the effectiveness of pesantren in addressing the socio-economic needs of the neighboring community, particularly the welfare development programs. 


\section{LITERATURE REVIEW}

\subsection{Background Theory}

A wide range of definitions delineates commercial economy, from highlighting economics as "the study of how people and societies choose to use the scarce resources that nature and past generations have supplied" (Parkin, 2016), to economics as "a science of behavior, or social science that studies how individuals make decisions" (Case, et al., 2017). On the other hand, the word "commercial" refers to commerce or general business activity (Poulsson and Kale, 2004). Commercial economy is therefore the study of how individuals make decisions to generate profit from business activity. As far as Islamic commercial economy is concerned, commercial economy could be referred to as one in Islamic perspective.

Pesantren carries out some business unit to promote the educational process and makes a great deal of effort to meet the requirements, such as establishing rice fields, rice mills, clove farming, palm oil garden, husbandry, chicken butchers, construction materials, food and beverage, canteen, grocery store, bakery, ice factory, sports shop, drug store, bookstore, chemists, transportation, book printing, book publishing, magazine, convection and others. Santri or students and asatidz or teachers carry out all these works while the income is spent to cover the needs of a pesantren and partially distributed for asatidz and santri to help defray the costs of their daily needs. Therefore, every company unit in pesantren aims to be secure and periodically enhanced for better profit accomplishment.

Social economy relates to creative activities with a social goal either in the for-profit industry (e.g., Dees \& Anderson, 2003; Bull \& Crompton, 1996) or in corporate social company (e.g., Austin, Leonard, Reficco, \& Wei-Skillern, 2004), or in the non-profit industry. The reality that the fundamental drive for social economy is to generate social value rather than private or shareholder wealth is common across all definitions of social economy.

Islamic economy is connected not only with commercial purposes but also with social purposes, such as zakah, infaq, and waqf, how individuals make decisions to generate business profit while at the same moment targeting spiritual benefits. The Prophet encouraged Umar Ibn Al-Khattab to keep the Khaibar land to make it a waqf to provide something more precious on the Khaibar territory so that he could give the profit to the poor, families, visitors and musafir (Bukhari, 1986, in Bulughul Maram 2002:211). Umar Ibn Al-Khattab, however, set aside his business aspect for the welfare of society. Therefore, Islamic economy not only relates to commercial purposes under Islamic economic system, but also social purposes with the same goal of achieving fallah.

In pesantren, while the khidmah or social service is implemented, the assatidz or teacher and the musyrif, the musyrifah or the companion of the santri are not compensated. However, they must be committed and hard workers. All tuition fees are fully spent on santris' needs, and there is no single rupiah allocated for the welfare of the teacher.

In recent decades, there has been an increase in economic activity with an integrated social purpose. In productive waqf, usually linked to religion and the socio-economic system of Muslim communities, Islamic business and social purposes are implemented. Waqf has evolved and extended so broadly that it is recognized as one of the key industries which contribute enormously to the production and development of human communities. 
Etymologically, the word waqf derived from waqf (Arabic), synonymous to habasa, which means to hold, to defend and to stop (فق ف), 2000: 54). In Islamic perspective, the word waqf means to hold a thing and spend its advantages in the way of Allah. The development of waqf assets is a picture of productive waqf. Productive waqf is a transformation or a new form of natural waqf into professional waqf in aspect of management.

In addition to the productive waqf, the Muslim Ummah has also experienced the evolution of Islamic educational institution, called pesantren. As one of the pioneers of Islamic education in Indonesia, pesantren used waqf for a long time to manage independently based on self-financing system. Hundreds of pesantren emerge and spread in major parts of the country, especially in Java. Both productive waqf and pesantren share common aims to promote welfare and has a significant feature of sustainability.

As far as the institution is concerned, the integration of Islamic commercial and social economy was able to encourage innovation. Older and bigger pesantrens have considerably greater levels of innovation than those of smaller and earlier. However, productive waqf is not only a significant part of pesantren's promotion of pesantren welfare, but also utilizes existing Islamic social and business integration.

\subsection{Previous Studies}

The integration of Islamic social and commercial economy is a new topic, in that the existing studies on this issue are scarce. The closest literature to this topic is the integration of Islamic commercial and social finance. Some of these studies include, among others, Ascarya, et al. (2017) and Safrina, et al. (2017).

Several models of the integration of Islamic social and commercial finance according to Ascarya, et al. (2017) includes 18 models, i.e. 6 models at the national level, 6 models at the community level and 6 models of micro-level. He proposed the possible model can be applied in financial institutions, namely (1) BUS-4 model where Islamic banks as Sharia financial institutions establish Baitul Maal as amil and nadzir, and Zakat-Waqf's funds placed in Islamic banks as LKS-PWU; (2) BPRS-4 model, this model is same as BUS-4's but in a smaller scale; (3) KMS3 model, where the BMT has Baitul Maal, which is equivalent to Baitut Tamwil, and each headed by a Manager under the administrators. Moreover, using descriptive analysis, Safrina, et al. (2017) concluded five strategies for integration of commercial and social Islamic finance to strengthen the sustainability of Islamic financial systems.

However, only few studies focus on the integration of Islamic commercial and social economy. Some of these studies are part of a financial integration especially through productive waqf models. Some of these studies include, among others, Thaker (2018), Haneef, et al. (2014) and Suhaimi, et al. (2014).

Thaker (2018) developed the integrated cash waqf model as a source of financing for micro enterprises. This study was aimed to observe the opinions and recommendations of various experts on Integrated Cash Waqf MicroEnterprises Investment (ICWME) model. The experts highlighted the importance of establishing, managing, and operating ICWME model under the aegis of the State Islamic Religious Council in Malaysia or the corporate sector. 
Haneef, et al. (2014) integrated the waqf institutions and Islamic microfinance (IMF) for a better outcome particularly for the welfare development of the OIC member countries. This model would also enhance the effectiveness of IMF and Waqf institutions in addressing the socio-economic needs of the society, particularly the poverty alleviation programs.

Similar approach to identify possible model for integration of Islamic commercial and social finance through productive waqf models has been done by Suhaimi, et al. (2014) by taking the case of share Waqf. Shared waqf fund scheme was established by the Islamic Religious Council, Majlis Agama Islam Negeri Pulau Pinang (MAINPP) in an effort to develop the economy of the Muslim community in the state. This study found that the share waqf scheme plays an important role in the economic development of the Muslim community in Penang. This is evident in the role that the shared waqf scheme plays in providing spirituality, financial, social, and welfare infrastructure for human resource development within the Muslim community. Ultimately, it contributes to providing of a financing facility to the purchase of waqf assets.

In addition, only few studies concentrate on the integration of Islamic commercial and social in pesantren. Therefore, this study aims to open up some avenues of exploration for Islamic social and commercial economy that can be transferred to an integration model to promote pesantren welfare. In other words, it examines the determinants of pesantren welfare through integration of four important elements. First, the productive waqf deals with the potential asset, management asset of productive waqf, professional nadzir, productive waqf financing, productive waqf regulation, and support for the factors of productive waqf.

Second, the business unit should include the source of fund of business unit, potential market, market need, profitability, business capital, business location, product innovation, and product quality. Third, project financing covers the firm establishment, facilities and infrastructure, project expansion, availability of the experts, and funding ability. Fourth, human resource should cover the qualified human resource, good manner or attitude, skills needed, work experience, job targeting, and quality of work.

To promote the pesantren welfare itself, we can use several indicator including the santri welfare, teachers welfare, staff worker welfare, educational development, supporting da'wah, economic empowerment, and expansion of pesantren activities. These five elements cover most of the integration of Islamic social and commercial in pesantren. Several indicators include the productive waqf itself, business unit, project financing, human resources, and pesantren welfare. See table 1. 
Table 1.

Literature Summary of Integration Model in Pesantren

\begin{tabular}{|c|c|}
\hline Variables & Reference \\
\hline \multicolumn{2}{|l|}{ Productive Waqf (PW) } \\
\hline 1. Potential Asset of PW & Mannan (2005); Zuki (2012 p.173) \\
\hline 2. Management Asset of PW & Rashid (2012 p.106); Shulthoni, et al. (2018 p.158) \\
\hline 3. Professional Nadzir & Khan (2015 p.48); Zuki (2012 p.174) \\
\hline 4. PW Financing & Kahf (1998 p.43); Mohsin (2009 p.306); Shulthoni, et al. (2018 p.158) \\
\hline 5. PW Regulation & Rashid (2012 p.108) \\
\hline 6. Supporting Factor of PW & Hasan (2006 p.4) \\
\hline \multicolumn{2}{|l|}{ Business Unit } \\
\hline 1. Source of Fund & Indrawati (2014 p.86); Ahwarumi, et al.(2018, p.357) \\
\hline 2. Potential Market & Razak, et al.(2016 p.126); Stahl (1987 p.785) \\
\hline 3. Market Need & Phillips (1983 p.32); Ahwarumi, et al.(2018, p.355) \\
\hline 4. Profitability & Bahroni (2012 p.359); Indrawati (2014 p.85); Phillips (1983 p.32) \\
\hline 5. Business Capital & Phillips (1983 p.32) \\
\hline 6. Business Location & Stahl (1987 p.759) \\
\hline 7. Product Innovation & Phillips (1983 p.32) \\
\hline 8. Product Quality & Phillips (1983 p.32) \\
\hline \multicolumn{2}{|l|}{ Project Financing } \\
\hline 1. Project Expansion & Ahwarumi, et al.(2018, p.360); Dhofier (1980 p.186) \\
\hline 2. Firm Establishment & Umam (2018); Dhofier (1980 p.114) \\
\hline 3. Facilities \& Infrastructure & Zuki (2012 p.175) \\
\hline 4. Availability of Experts & Bahroni (2012 p.343) \\
\hline 5. Funding Ability & Shulthoni, et al. (2018 p.158) \\
\hline \multicolumn{2}{|l|}{ Human Resource } \\
\hline 1. Qualified Human Resource & Kamri (2010 p.666); Siswanto, et al. (2013 p.51) \\
\hline 2. Good Manner/Attitide & Asadullah (2006 p.16); Kamri (2010 p.670); Febriyanti (2018 p.322) \\
\hline 3. Skills Needed & Isbah (2006 p.174); Rashid (2012 p.109); Febriyanti (2018 p.322) \\
\hline 4. Work Experience & Bahroni (2012 p.358); Febriyanti (2018 p.320) \\
\hline 5. Job Targetting & Kamri (2010 p.670) \\
\hline 6. Quality of Work & Bahroni (2012 p.359); Febriyanti (2018 p.322) \\
\hline \multicolumn{2}{|l|}{ Pesantren Welfare } \\
\hline 1. Santri Welfare & Dhofier (1980 p.147); Ahwarumi, et al.(2018, p.356) \\
\hline 2. Teachers Welfare & Dhofier (1980 p.147); Febriyanti (2018 p.319) \\
\hline 3. Staff Worker Welfare & Dhofier (1980 p.188) \\
\hline 4. Educational Development & $\begin{array}{l}\text { Razak, et al. (2016 p.126); Bahroni (2012 p.360); Ahmad \& Hassan } \\
\text { (2015 p.49); Isbah (2006 p.120) }\end{array}$ \\
\hline 5. Supporting $\mathrm{Da}^{\prime}$ wah & Isbah (2006 p.140) \\
\hline 6. Economic Empowerment & Isbah (2006 p.125); Febriyanti (2018 p.319) \\
\hline $\begin{array}{l}\text { 7. Expansion of Pesantren } \\
\text { Activities }\end{array}$ & Dhofier (1980 p.186); Ahwarumi, et al.(2018, p.360) \\
\hline
\end{tabular}




\subsection{Conceptual Framework}

The researchers build the following conceptual and empirical structure on the basis of the above literary reviews. The three latent endogenous variables, namely business unit, project financing, and human resources are provided as described in Figure 1. The researchers also include the productive waqf, a latent exogenous variable.

The alternative goals on proxies for the pesantren welfare are to increase santri welfare, the welfare of teachers, the welfare of staff members, the education development, the supporting of da'wah, the empowerment of the economy, and the expansion of activities by the pesantren. Any rise in one or more of these proxies will show a positive indication of pesantren welfare.

In this context, the researchers build, assess, and validate our empirical model. The results of the estimate and the assessment will be used to draw the conclusions. The outcome is expected to lead to several policy suggestions on how to help encourage pesantren welfare in the integration model.

\section{Figure 1. \\ Conceptual Framework of Islamic Social and Commercial Integration in Pesantren Model}

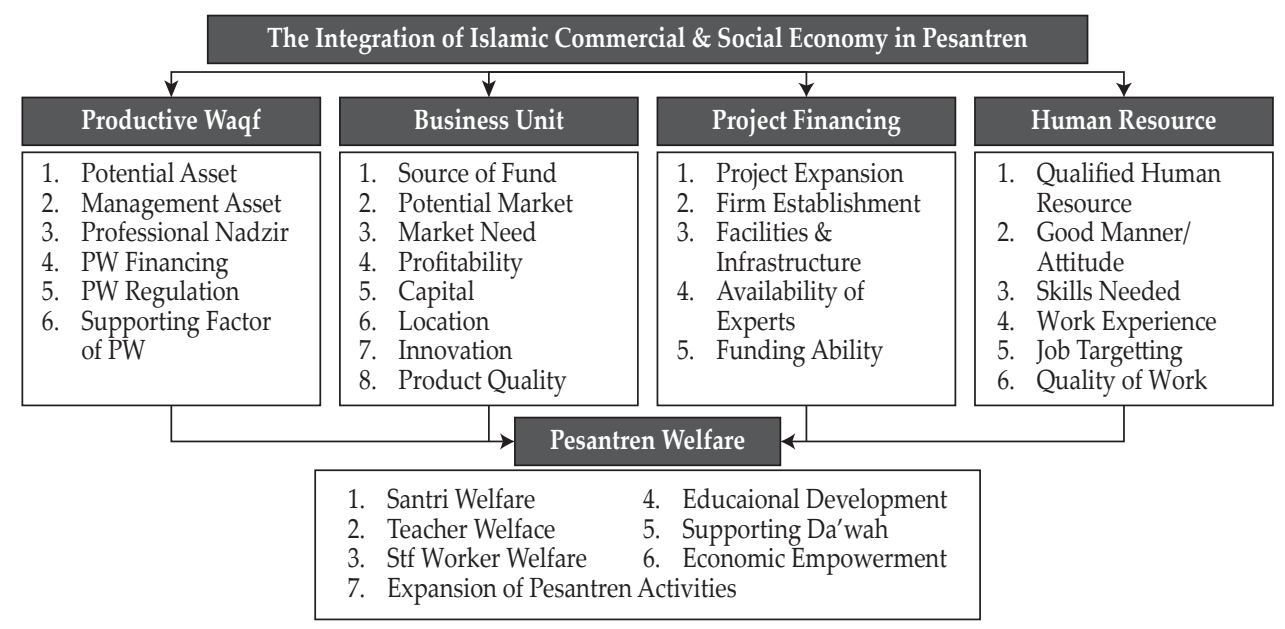

Source: various sources gathered by the authors

\section{METHODOLOGY}

\subsection{Data}

A survey distributed to pesantren in Java and Sumatra, Indonesia was analyzed quantitatively to test the hypotheses. The respondents for the survey in this study were the operational chief, assatidz or teacher, musyrif, musyrifah or santri companion and santri or students in waqf-based pesantren. A sample size of between 200 and 400 is considered sufficient on average for good results (Hair, et al., 2010). It is also suggested that for every statistical analysis at least 200 is also useful (Hoe, 2008). 
Some people would rather bring the sample according to the amount of study parameters or objects. A sample size of at least 100 is permissible in other studies using the Structural Equation Model (SEM) (Wijayanto, 2015). Bagozzi and Yi (2012) also support his opinion that more than 100 people should be SEM sample size. These opinions has been implemented by this study (Wijayanto, 2015; Bagozzi and $Y i, 2012$ ) and the original sample size was determined by 263 operational chief, assatidz or teacher, musyrif, musyrifah or santri companion and santri or students in waqf-based Pesantren.

\subsection{Model Development}

The new model that integrates the Islamic commercial enterprises of Pesantren with productive waqf as the Islamic social financial instrument to increase a pesantren's welfare effectively was suggested in this section. The suggested integrated Islamic commercial and social economy in the Pesantren model, composed of five important parts, led in six hypotheses to be tested. These hypotheses are obtained from the prospective linkages expected between the model to the welfare of pesantren.

SEM model of this study comprises of a latent exogenous variable, namely Productive Waqf $\left(\xi_{1}\right)$, as well as four latent endogenous variables, namely Business Unit $\left(\eta_{1}\right)$, Project Financing $\left(\eta_{2}\right)$, Human Resource $\left(\eta_{3}\right)$, and Pesantren welfare $\left(\eta_{4}\right)$. Table below shows the latent variable's comprehensive indicators.

Table 2.

Developed Indicators of Islamic Social and Commercial Integration in Pesantren Model

\begin{tabular}{|c|c|}
\hline Productive Waqf $\left(X_{1}\right)$ & Business Unit $\left(\mathrm{Y}_{1}\right)$ \\
\hline $\mathrm{X}_{1}$ : Potential Asset of PW & $Y_{1}:$ Source of Fund \\
\hline $\mathrm{X}_{2}$ : Management Asset of PW & $\mathrm{Y}_{2}:$ Potential Market \\
\hline$X_{3}:$ Professional Nadzir & $\mathrm{Y}_{3}:$ Market Need \\
\hline$X_{4}:$ PW Financing & $\mathrm{Y}_{4}:$ Profitability \\
\hline$X_{5}:$ PW Regulation & $Y_{5}:$ Business Capital \\
\hline$X_{6}:$ Supporting Factor of PW & $\mathrm{Y}_{6}:$ Business Location \\
\hline \multirow[b]{2}{*}{ Human Resource $\left(Y_{3}\right)$} & $\mathrm{Y}_{7}:$ Product Innovation \\
\hline & $\mathrm{Y}_{8}:$ Product Quality \\
\hline$Y_{14}:$ Qualified Human Resource & Project Financing $\left(\mathrm{Y}_{2}\right)$ \\
\hline $\mathrm{Y}_{15}:$ Good Manner/Attitide & $Y_{8}:$ Project Expansion \\
\hline$Y_{16}:$ Skills Needed & $Y_{10}:$ Firm Establishment \\
\hline $\mathrm{Y}_{17}:$ Work Experience & $Y_{11}:$ Facilities \& Infrastructure \\
\hline $\mathrm{Y}_{18}$ : Job Targetting & $Y_{12}:$ Availability of Experts \\
\hline $\mathrm{Y}_{19}:$ Quality of Work & $Y_{13}:$ Funding Ability \\
\hline \multicolumn{2}{|c|}{ Pesantren welfare $\left(\mathrm{Y}_{4}\right)$} \\
\hline $\mathrm{Y}_{20}$ : Santri Welfare & $Y_{23}:$ Educational Development \\
\hline$Y_{21}:$ Teachers Welfare & $\mathrm{Y}_{24}:$ Supporting $\mathrm{Da}^{\prime}$ wah \\
\hline $\mathrm{Y}_{22}:$ Staff Worker Welfare & $\mathrm{Y}_{25}:$ Economic Empowerment \\
\hline $\mathrm{Y}_{26}$ : Expansion of Pesantren Activities & \\
\hline
\end{tabular}


The comprehensive empirical SEM model of this study is shown in Figure 2, which provides productive waqf, business unit, project financing, human resource, which can integrate Islamic commercial and social economy for the welfare of Pesantren.

Figure 2.

Developed Model of Islamic Social and Commercial Integration in Pesantren

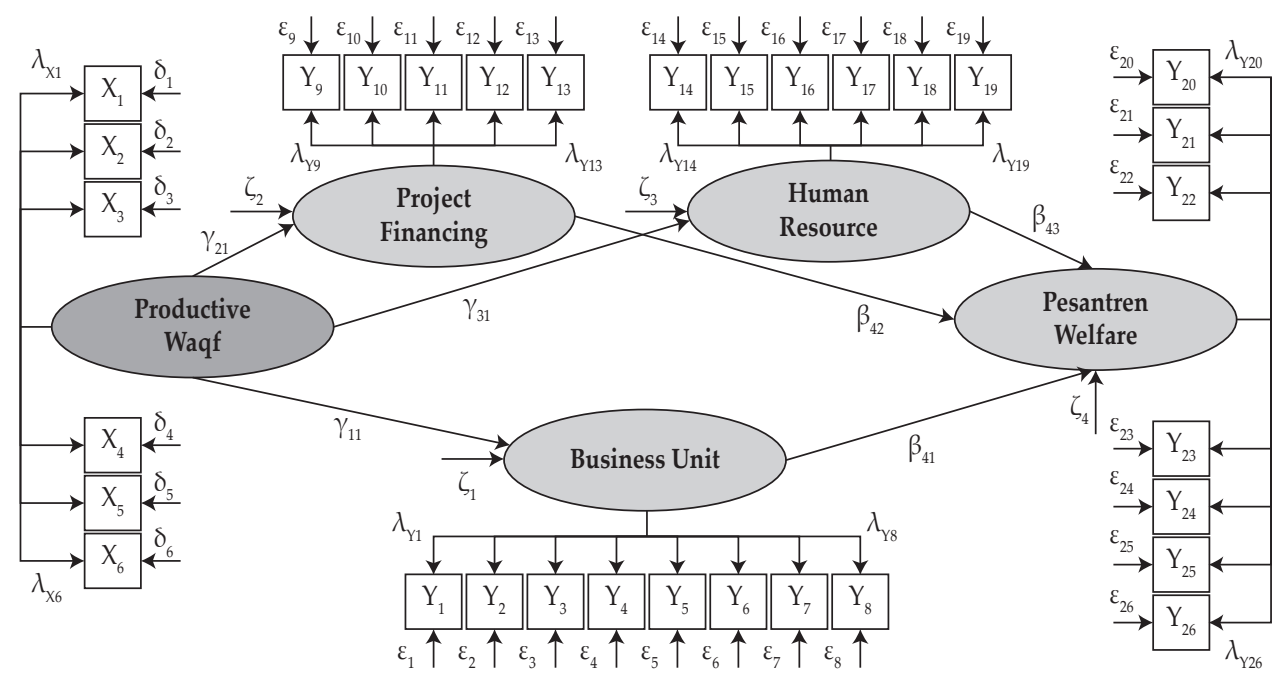

\subsection{Methods}

Karl Jöreskog (1973) has created structural Equation Model (SEM) in combination with a Keesling (1973) and Wiley (1973) model (Ascarya \& Rahmawati, 2018). It is well known as "Linear Structural Relationship" or LISREL. The software for SEM version 8.70 of Lisrel was used to provide fitness indices and assess how well the information suits the suggested model.

SEM is commonly used in several conduct science studies. It is a comprehensive statistical method combining the CFA and structural model into a combined statistical test (Ascarya \& Rahmawati, 2018). It is an effective method for the evaluation and testing of inferential information. One benefit of SEM is that it simultaneously measures several variables and their links. It also enables several dependent relations among the variables (Wijayanto, 2015).

Prior to SEM, the latent structures were analyzed to evaluate how far findings would follow the theory and estimate the constructs in the suggested model. A test was performed on latent constructs. Accordingly, five constructs or components of the integrated Islamic commercial and social economy in the Pesantren model, namely (i) Productive Waqf, (ii) Business Unit, (iii) Project Financing, (iv) Human Resource, and (v) Pesantren welfare were entered into SEM as unobserved variables.

Such a method enabled the researchers to apply this multivariate technique to validate the relationships between the unobserved variables (Hair, et al., 2010). 
Pesantren welfare, for example, is one part or unobserved variables derived from the factors observed, such as expansion of pesantren activities, economic empowerment, educational development, supporting da'wah, and others.

In SEM, unidirectional arrows indicate the routes of regression. For example, the unidirectional arrow in the integrated Islamic commercial and social economy in the Pesantren model points to the endogenous factor, pesantren welfare, assumes that exogenous factor namely business unit, project financing and human resource "cause" pesantren welfare (see in Figure 5). Pesantren welfare is identified in the integrated Islamic commercial and social economy in the Pesantren model as the dependent variable.

\subsubsection{Measurement and Structural Model}

The two primary components of the SEM model are a combination of factor analysis and path analysis: (1) the measurement model and (2) the structural model. The former is a model that examines the connection and demonstrates cause relationships between the latent variables and their indicators, while the latter the relation between latent variables. In estimating the latent variable value, the former uses the causal relationship to require several measured indices. The latent variable cannot be observed and may be endogenous or exogenous, whereas both of the indicators are observed.

$\mathrm{Xn}$, the latent exogenous indicators, with causal dependence known as $\lambda \mathrm{Xn}$ "lambda $\mathrm{Xn}$ " and $\delta \mathrm{n}$ 'delta' is generally referred to measurement error for latent exogenous. The other side is, $\mathrm{Yn}$, the latent endogenous indicator, with causal dependence known as $\lambda Y_{n}$ "lambda $Y_{n}$ " and En 'epsilon' is referred to measurement error for latent endogenous.

Figure 3.

\section{Measurement Model of SEM}
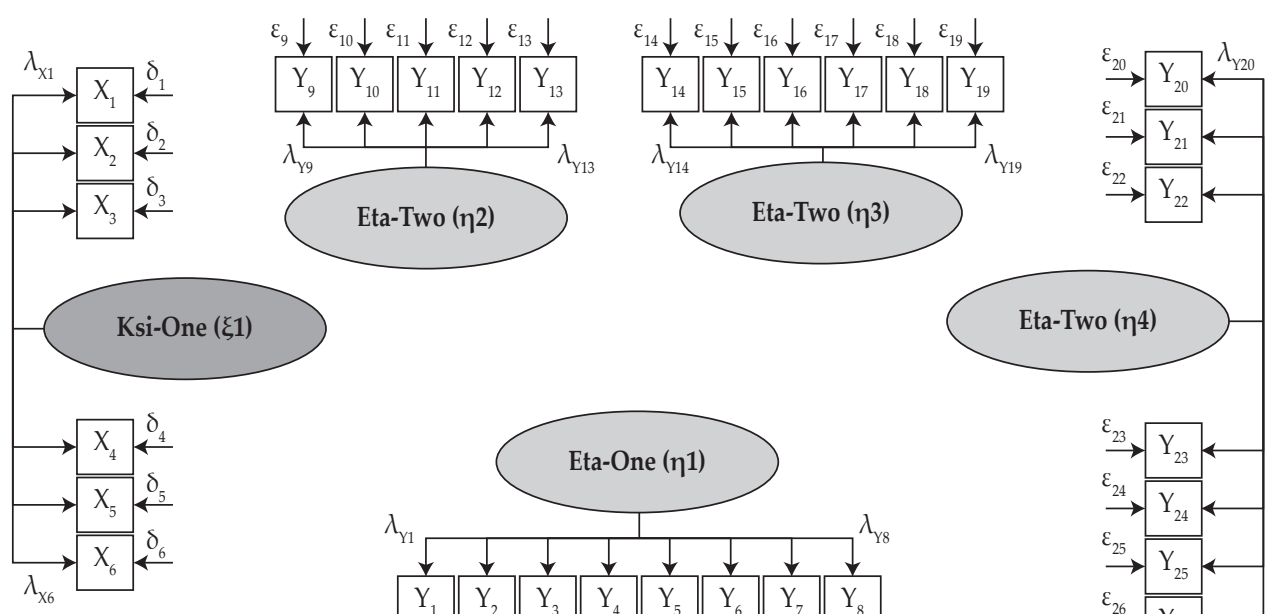

Eta-Two ( $\eta 2)$ 
Figure 3 illustrates the examples of measurement models. Moreover, the measurement models can be reinterpreted into the following equations.

Latent exogenous $\xi 1$ :

$$
X_{1}=\lambda x_{1} \xi_{1}+\delta_{1} \ldots X_{6}=\lambda x_{6} \xi_{6}+\delta_{6}
$$

Latent endogenous $\eta 1$ :

$$
\mathrm{Y}_{1}=\lambda \mathrm{y}_{1} \eta_{1}+\varepsilon_{1} \ldots \mathrm{Y}_{8}=\lambda \mathrm{y}_{8} \eta_{1}+\varepsilon_{8}
$$

Latent endogenous $\eta 2$ :

$$
\mathrm{Y}_{9}=\lambda \mathrm{y}_{9} \eta_{2}+\varepsilon_{9} \ldots \mathrm{Y}_{13}=\lambda \mathrm{y}_{13} \eta_{2}+\varepsilon_{13}
$$

Latent endogenous $\eta 3$ :

$$
\mathrm{Y}_{14}=\lambda \mathrm{y}_{14} \eta_{3}+\varepsilon_{14} \ldots \mathrm{Y}_{19}=\lambda \mathrm{y}_{19} \eta_{3}+\varepsilon_{19}
$$

Latent endogenous $\eta 4$ :

$$
\mathrm{Y}_{20}=\lambda \mathrm{y}_{20} \eta_{4}+\varepsilon_{20} \ldots \mathrm{Y}_{26}=\lambda \mathrm{y}_{20} \eta_{4}+\varepsilon_{26}
$$

Meanwhile, the structural model refers to the direct relation between latent variables, known as by $\xi$ 'Ksi' for latent exogenous and $\eta$ 'Eta' for latent endogenous. The endogenous variables, however, serve as mediating or puredependent factors, but they are not initially causal variables. Exogenous and endogenous factors generally have causal interaction and are expressed directly in a single headed arrow with $\gamma$ 'gamma', while $\beta$ 'beta' is typically referred to as the cause of two endogenous variables. Error is generally marked $\zeta$ 'zeta' in the structural equation of an endogenous variable and constitutes the part that the model cannot explain.

Figure 4.

Structural Model of SEM

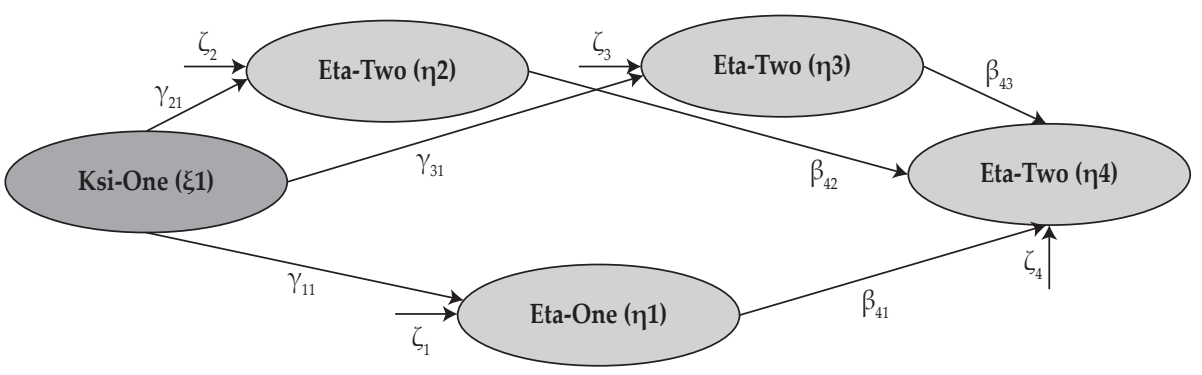

Figure 4 illustrates the examples of structural models. Moreover, these structural models can be reinterpreted into the following equations. 


$$
\begin{aligned}
& \eta_{1}=\gamma_{11} \xi_{1}+\zeta_{1} \\
& \eta_{2}=\gamma_{21} \xi_{1}+\zeta_{2} \\
& \eta_{3}=\gamma_{31} \xi_{1}+\zeta_{3} \\
& \eta_{4}=\beta_{41} \eta_{1}+\beta_{42} \eta_{2}+\beta_{43} \eta_{3}+\zeta_{4}
\end{aligned}
$$

\subsubsection{SEM Procedure}

SEM comprises 5 phases: 1) Specification; 2) Identification; 3) Estimation; 4) Goodness of Fit Test; and 5) Respecification (Ascarya \& Rahmawati, 2018). The model specification comprises translating the verbal hypotheses into a sequence of equations previously shown as a path diagram. Figure 5 demonstrates a path diagram suggested to encourage pesantren welfare in the research of integration of the Islamic social and commercial economy.

Figure 5.

SEM Procedure

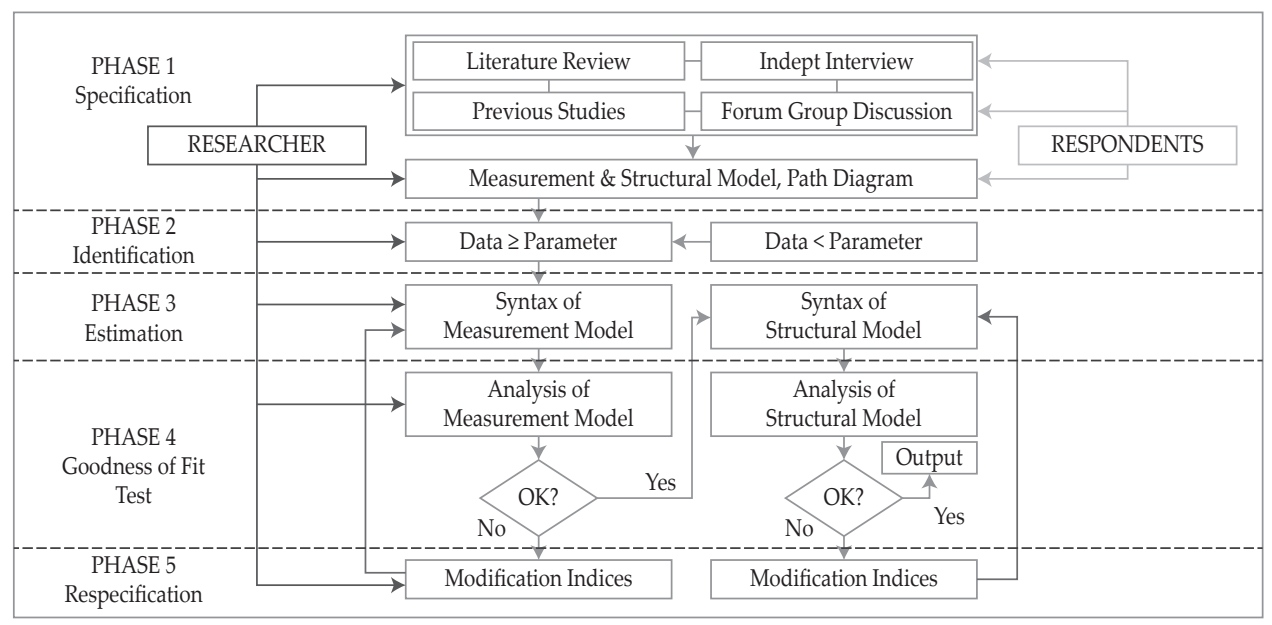

Source: Ascarya \& Rahmawati (2018) modified by the authors

In this second phase, the information on all observable factors specified in the model are gathered, in that the model parameter can be derived from an observable set of variance and covariance. The third phase is intended to predict the parameter value, such as the standardized path coefficients. There is a huge number of literature in this field, which results in a serial range of estimation techniques, such as Generalized Least Square (GLS), Unweighted Leas Square (ULS), Generally Weighted Least Square (WLS), and Maximum Likelihood (ML), which is the most used according to Browne (1984).

The next phase is the statistical process to evaluate whether this model is compatible with the information. This is achieved through a goodness of fit test. 
Because of their complexity, models are generally dismissed by the goodness of fit test, in that the model requires to be changed to enhance its fit or simplicity at this last phase. The SEM stage summary is illustrated in the Figure 5.

In SEM, unidirectional arrows indicate the routes of regression. For example, the unidirectional arrow in the integrated Islamic commercial and social economy in the Pesantren model points to the endogenous factor, pesantren welfare, assumes that exogenous factor namely business unit, project financing and human resource "cause" pesantren welfare (see in Figure 2). Pesantren welfare is identified in the integrated Islamic commercial and social economy in the Pesantren model as the dependent variable.

\section{RESULTS AND ANALYSIS}

\subsection{SEM Results: Measurement Model}

The results of five measurement models will be discussed, consisting of one latent exogenous variable (productive waqf) and four latent endogenous variables (business unit, project financing, human resources, and pesantren welfare).

Table 3.

Fit Indices for Measurement Models

\begin{tabular}{lccccc}
\hline \multirow{2}{*}{ Fit Index } & \multicolumn{3}{c}{ Latent Exogenous } & \multicolumn{4}{c}{ Latent Endogenous } \\
\cline { 2 - 6 } & PW & BU & PF & HR & P'sW \\
\hline$\chi^{2}$ & 23.56 & 28.88 & 9.29 & 3.770 & 7.79 \\
$\mathrm{df}$ & 9 & 19 & 5 & 6 & 8 \\
$\chi^{2} / \mathrm{df}$ & $2.617^{*}$ & $1.520^{*}$ & $1.860^{*}$ & $0.628^{*}$ & $0.973^{*}$ \\
$\varrho$ & 0.005 & 0.067 & $0.097^{*}$ & $0.707^{*}$ & $0.454^{*}$ \\
RMSEA & $0.790^{*}$ & $0.045^{*}$ & $0.057^{*}$ & $0.000^{*}$ & $0.000^{*}$ \\
RMR & $0.028^{*}$ & $0.032^{*}$ & $0.029^{*}$ & $0.011^{*}$ & $0.015^{*}$ \\
GFI & $0.971^{*}$ & $0.973^{*}$ & $0.986^{*}$ & $0.995^{*}$ & $0.992^{*}$ \\
AGFI & $0.932^{*}$ & $0.949^{*}$ & $0.958^{*}$ & $0.983^{*}$ & $0.971^{*}$ \\
NNFI & $0.943^{*}$ & $0.975^{*}$ & $0.978^{*}$ & $1.010^{*}$ & $1.001^{*}$ \\
CFI & $0.966^{*}$ & $0.983^{*}$ & $0.989^{*}$ & $1.000^{*}$ & $1.000^{*}$ \\
\hline
\end{tabular}

Note: PW (Productive Waqf); BU (Business Unit); PF (Project Financing); HR (Human Resource); P'sW (Pesantren Welfare); $\chi^{2}=$ chi square, minimum fit function test $\left(\chi^{2} / \mathrm{df} \leq 3.0\right)$; $\mathrm{Q}=\mathrm{p}$-value $(>0.08)$; RMSEA $=$ root mean square error of approximation $(\leq 0.08) ; \mathrm{RMR}=$ standardized root mean square residual $(\leq 0.10)$; $\mathrm{GFI}=$ goodness fit index $(\geq 0.90)$; AGFI $=$ adjusted GFI $(\geq 0.90)$; NNFI = non-normed fit index $(\geq 0.90)$; CFI $=$ comparative fit index $(\geq 0.90)$

Source: data processed by the authors

Fit indices for the measurement model designed to assess the pesantren welfare are presented in Table 3. The LISREL modification index was examined to determine whether adding or reducing indicators to the hypothesized model was required. In assessing measurement models, we did not depend on chisquare measurements to evaluate general fit due to their sensitivity to a number of samples as well as other biases. The suggested five measurement models fit the data best among the alternative measurement models based on the chosen fit 
indices, either from a statistical $(\chi 2=7.79 ; \mathrm{df}=8 ; \mathrm{Q}=0.973)$ or a practical (RMSEA = 0.00 , and $\mathrm{RMR}=0.02 ; \mathrm{GFI}=0.99, \mathrm{AGFI}=0.97, \mathrm{NNFI}=1.00 ; \mathrm{CFI}=1.00$ ) perspective.

The RMSEA values, all being less than 0.08 , stated that the five measurement models constructed appropriate measurement models. The goodness-of-fit index also reached 0.90 , implying that the proposed indicators could explain more than 90 percent of item variances and covariances. Overall, the results indicated that the five measurement model for the constructs of the integrated Islamic commercial and social economy in the Pesantren fit the data moderately.

The model in Figure 6 is a measurement model of the integrated Islamic commercial and social economy in the Pesantren. In this model, each of the five latent variables is represented by five until eight measured variables, called indicators.

Figure 6.

Measurement Result of Islamic Social and Commercial Integration in Pesantren

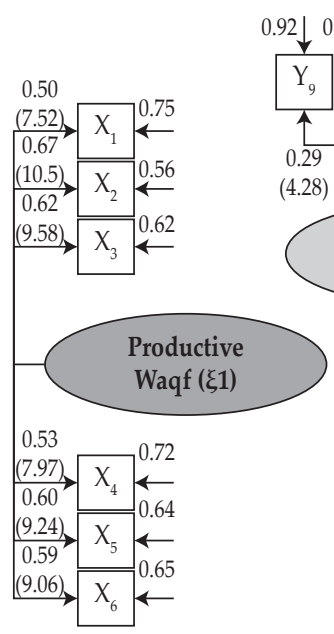

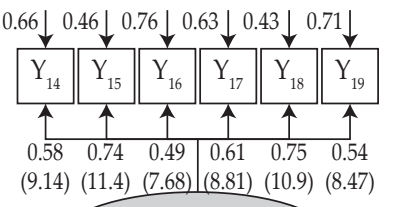

Human

Resource $(\eta 3)$
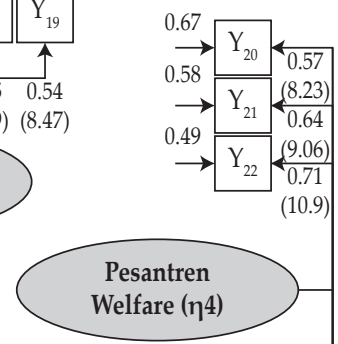

Project Financing $(\eta 2)$

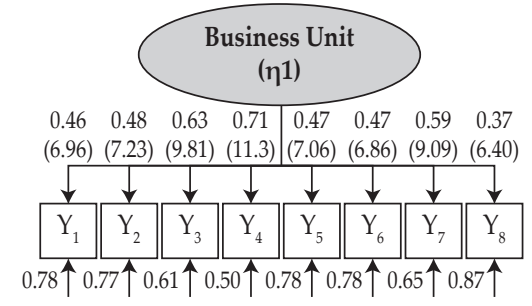

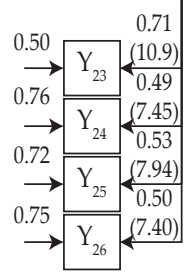

Source: data processed by the authors

Figure 6 illustrates estimates of the measurement model coefficients for the Integrated Islamic Commercial and Social Economy in the Pesantren model. Each coefficient can be considered as a standardized regression coefficient of one exogenous or endogenous indicator or measured variables on its related latent variable when the effects of other indicators or measured variables were partialed out. All path coefficients were positive in the direction and statistically significant. Overall, the results indicated that the twenty six indicator or measured variables significantly explain each five latent variables.

Moreover, from the aspect of factor analysis, factor loading is the correlation between the observed variable score and the latent variable score. Generally, the greater the better, since the factor loading square can be directly translated as 
item reliability. The maximum Standardized Loading Factor (SLF) of productive waqf variable is $X_{2}$ management asset of productive waqf $(0.67)$ and accompanied by $X_{3}$ professional nadzir (0.62). The maximum SLF of business unit variable is $\mathrm{Y}_{4}$, profitability (0.71) and followed by $\mathrm{Y}_{3}$, market needs $(0.63)$ and $\mathrm{Y}_{7}$, product innovation (0.59). The maximum SLF of project financing variable is $Y_{11}$, facilities and infrastructure (0.81) and accompanied by $\mathrm{Y}_{10}$, firm Establishment (0.67) as well as $Y_{13}$, funding ability. The maximum SLF of human resource variable is $Y_{18}$, job targeting (0.75), followed by $Y_{15}$, good manner or attitude (0.74) and $Y_{17}$, work experience $(0.61)$. The maximum SLF of pesantren welfare variable is $Y_{22,}$, staff worker welfare (0.71) and $Y_{23}$, educational development (0.71), and followed by $\mathrm{Y}_{21}$, assatidz or teacher, musyrif, musyrifah, or santri companion welfare (0.64).

\subsection{SEM Results: Measurement Model}

Fit indices for the structural model designed to assess the pesantren welfare are presented in Figure 7. The results show that the suggested structural models fit the data best among the alternative structural models based on the chosen fit indices, either from a statistical $(\chi 2=7.79 ; \mathrm{df}=8 ; \mathrm{Q}=0.000)$ or a practical (RMSEA $=0.065$, and $\mathrm{RMR}=0.059 ; \mathrm{GFI}=0.823, \mathrm{AGFI}=0.783, \mathrm{NNFI}=0.939 ; \mathrm{CFI}=0.947$ ) perspective. The RMSEA values (all were less than 0.08) stated that the structural models constructed appropriate structural models. The goodness-of-fit index also reached 0.80 , indicating that the proposed variables could explain more than 80 percent of item variances and covariances. Overall, the results indicated that the structural model for the constructs of the integrated Islamic commercial and social economy in the Pesantren fitted the model moderately.

Figure 7.

Structural Result of Islamic Social and Commercial Integration in Pesantren

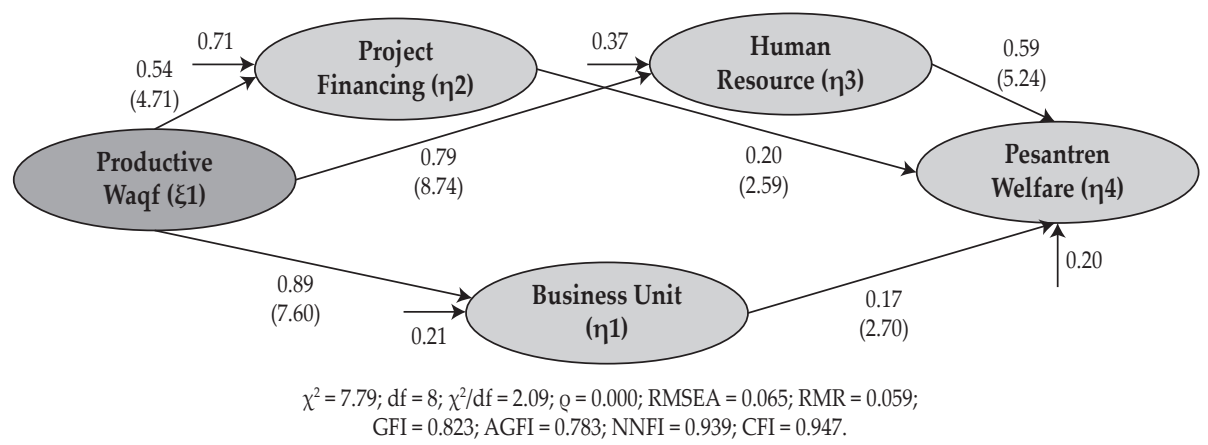

Source: data processed by the authors

Figure 7 presents the estimates of the structural coefficients for the integrated pesantren model. Each coefficient can be referred to as a standardized regression coefficient of latent exogenous variable on its linked latent endogenous variable. All of the path coefficients were statistically significant and positive in direction. The results suggested that productive waqf has direct and indirect significant 
effects on pesantren welfare. Three commercial economy variables in pesantren, i.e., business unit, project financing, and human resource, served as mediators of the relations between the Islamic social economy activities in pesantren through productive waqf and pesantren outcomes.

However, the variables appear to influence the pesantren welfare in different ways. The results suggested that although business unit were important in absorbing productive waqf activities, they had small effects on the outcomes. Project financing appeared to be more important than business unit in determining pesantren outcomes through productive waqf. The estimates of the path coefficients indicated that productive waqf had a strong relationship with business unit (0.89), which served as a mediator related to pesantren outcome (0.17).

In contrast, productive waqf had little influence on project financing (0.54). Moreover, productive waqf had a strongest relationship with human resources (0.79), which served as a mediator related to pesantren outcome (0.59). The vision of pondok pesantren is to construct autonomy in the economy. Pondok pesantren graduates were many intellectual Muslims recognized as santri graduates who play a role not only as a teacher of religion, but also as an entrepreneur and an economic agent in promoting pesantren products.

\subsection{Analysis}

This study is appropriate with Kahf's theory in productive waqf asset management (1998). This study was supposed to discuss and examine a productive waqf model in pesantren by integrating Islamic social finance and commercial economy or profitable business activities. Based on this study, the integrated model through productive waqf means more professional nadzir (Khan, 2015; Zuki, 2012) having access to manage the productive waqf, including its financing (Kahf, 1998; Mohsin, 2009), regulation (Rashid, 2012), facilities and infrastructure (Hasan, 2006), which support the development of productive waqf.

Islamic social finance sourced from waqf asset is allocated to the business unit and project financing of its pesantren. Business unit in pesantren is located on the pesantren, while project financing generally outside pesantren for example, a gas station is built as a subsidiary company to meet the needs of the pesantren. Islamic social finance indicator was waqf asset, which manages to fulfill the needs, and it can generate pesantren income to boost its welfare.

The influence of productive waqf to the business unit, project financing, as well as to the educational development of assatidz, musyrif, musyrifah and santri in pesantren is defined as the integration of Islamic social and commercial economy. Such integration is aimed to promote the pesantren welfare through productive waqf. Consequently, the waqf productive model should be further improved and integrated to promote the pesantren welfare.

Moreover, the operational chief, assatidz or teacher, musyrif, musyrifah or santri companion, and santri or students in pesantren, becomes a professional of the following aspects, i.e. Islamic social finance and commercial economy or profitable business activities. The professional nadzir must have a good manner or attitude (Asadullah, 2006; Febriyanti, 2018). They must acquire an expertise, ability, competence, and mastery in waqf (Isbah, 2006; Rashid, 2012), both fiqh 
waqf and asset investment. Work experience acquired during the study becomes significant for a nadzir to be much more employable to manage productive waqf (Bahroni, 2012).

In brief, a professional nadzir must be a qualified Islamic human resource (Kamri, 2010; Siswanto, et al., 2013). These spirit of self-reliance introduced by most pesantren in Indonesia through multiple activities inside the pesantren, such as economic enterprise, is one of the comprehensive process of educational activities in pesantren. Accordingly, human resource serves as the most important variable in this integrated model, as a santri is expected to transmit the knowledge to people so that more people understand the productive waqf.

Based on the integrated model of Islamic commercial and social economy in pesantren, productive waqf asset management is rather distinguished, interesting, and unique. A pesantren does not depend on the government financial support or other donations to enhance its educational program. Business units, organized by assatidz, musyrif, musyrifah, and santri are under direct supervision of kyai or the head master of pesantren, who would then assume the business units as the economic pesantren structured to promote the education process and thus fulfilling the needs of Pesantren's well-being and waqf empowerment.

In Indonesia, real-sector investment has been developed by several pesantren such as the establishment and formation of limited liability companies (PT or CV Company, no shares involved) (Umam, 2018; Dhofier, 1980). In the construction of such a project, a significant capital is needed (Ahwarumi, et al., 2018). Many pesantrens allocate productive waqf as a significant capital to develop the project. The form of financing can be encountered like waqf sukuk (Islamic bonds). When the project starts running, other additional factors need to be developed, such as the development of facilities and infrastructure (Shulthoni, et al., 2018) to conveniently support the pesantren community and external consumers.

Taken as whole, the study shows that productive waqf, business unit, project financing, and human resource have a strong relationship with the pesantren welfare in many ways. In relation with units of business in pesantren and profitable commercial activities, the human resource has its significant role to assist pesantren tries its level best to realize developed productive waqf.

\section{CONCLUSION AND RECOMMENDATION}

\subsection{Conclusion}

The study was conducted to validate the instrument developed using empirical data in several waqf-based pesantren in Indonesia. The results of the pilot survey show that the instruments were valid and reliable. Additionally, the inference is drawn from the result of the constructs validity tests and the structural equation modeling.

In brief, the results show that certain five structures have a substantial effect on the promotion of pesantren welfare. All structures were statistically significant and positive in developing pesantren welfare, especially to manage independently based on its self-financing system. Meanwhile, the productive waqf managed by kyai, asatidz, musyrif or musyrifah has significant direct and indirect effects on the welfare of pesantren. Three factors of the commercial economy in pesantren, i.e., 
business unit, project financing, and human resource, served as mediators of the integrated model for Islamic social and commercial economy in the pesantren.

\subsection{Recommendation}

Although an overwhelming number of pesantren, no matter how small in the suburban area or how remote in some other regions it is, and of people have wakaf confidence, most kyai, asatidz or teachers, musyrif or musyrifah, have lack of significant information to maintain productive waqf. They know its purpose, but do not fully understand the system to generate profit from waqf assets. They seem to be satisfied with what they have achieved. Therefore, to them there is no immediate need for pesantren development, improvement, and expansion.

In addition to the role of pesantren in productive waqf, Bank Indonesia should issue a policy that supports the pesantren empowerment as the foundation for national economic growth. This duo institution has common objectives of halal economy or halal value chain ecosystem. Possibly, it can be formed by Islamic social finance, e.g., using productive waqf.

Based on this study, BI, Sharia Finance National Committee (KNKS), various industry players, and other relevant government institutions should address the problems a pesantren faces to handle productive waqf and integrate Islamic social and commercial economy. First, developing prospective business units facilitating and using government networking and collaboration. Second, pesantren can develop its holding system by promoting project financing between pesantren and the regulators. Last but not least, drafting the model of this integration of Islamic and commercial economy model may be implemented by each pesantren to manage their productive waqf.

However, some limitations of the study are noticeable. The study should be conducted even in smaller pesantren or the remote areas of some other regions, thus the study could generate diverse outcomes and supporting the proposed model. Generally, it is therefore recommended that the further study should emphasize more on the sampling size, techniques, and survey areas with proper instruments development.

\section{REFERENCES}

Ahmad, M. \& Hassan, Y.B. (2015). Funding the Sub-Saharan African Education Sector with Waqf: Experiences from al-Azhar University and Selected Universities in Malaysia. Journal of Creative Writing, 1(2).

Ahwarumi, B., Sawarjuwono, T. \& Mawardi I. (2018). Roles of Business Incubator in Sunan Drajat Pesantren in Generating Islamic Entrepreneurs. In International Conference on Islamic Finance, Economics and Business, KnE Social Sciences (pp. 351-362).

Al 'Asyqolani, H. Ibn Hajar. (2002). Bulughul Maram. Beirut: Darul Kkutub Al Islamiyah.

Asadullah, M.N. \& Chaudhury, N. (2006). Religious Schools, Social Values and Economic Attitudes: Evidence from Bangladesh. QEH Working Paper Series 139. 
Ascarya. Husman, J.A., \& Suhart, U. (2017). Integrasi Keuangan Komersial dan Sosial Islam: Usulan Model (Working Paper). Jakarta: Bank Indonesia.

Ascarya. \& Rahmawati, S. (2017). Analysis of Determinants of Micro Enterprises Graduation. Journal of Islamic Economics, Banking and Finance, 14(1), 12-50.

Austin, J.E., Leonard, H., Reficco, E., \& Wei-Skillern, J. (2004). Corporate Social Entrepreneurship: A New Vision of CSR. (Working Paper No. 05-021). Boston: Harvard Business School.

Bagozzi, R. P. \& Yi, Y. (2012). Specification, Evaluation, and Interpretation of Structural Equation Models, Journal of the Academy of Marketing Science, 40, 8-34.

Bahroni, I. (2012). Streamlining Education Institution Through Waqf Enlargement: An Experience of Gontor System. Jurnal At-Ta'dib, 7(2).

Browne, M.W. (1984). Asymtotically Distribution-Free Methods for the Analysis of Covariance Structures. British Journal of Mathematical and Statistical Psychology, 37, 62-83.

Bull, M. \& Crompton, H. (2006). Business Practices in Social Enterprises. Social Enterprise Journal, 2(1).

Case, K.E., Fair, R.C., and Oster, S.E. (2017). Principles of Macroeconomics (12th ed.). London: Pearson Education.

Dees, J.G. \& Anderson, B.B. (2003). For-Profit Social Ventures. International Journal of Entrepreneurship Education (Special Issue on Social Entrepreneurship), 2, $1-26$.

Dhofier, Z. (1980). The Pesantren Tradition: A Study of the Role of the Kyai in the Maintenance of the Traditional Ideology of Islam in Java (Doctoral Thesis). Australian National University.

Febriyanti, F., Affandi, I., \& Danial, E. (2018). Model Economic Development of Civics in Character Formation Plus Entrepreneurial Behavior-Based Self Reliance in the Pesantren. Advances in Social Science, Education and Humanities Research, 251.

Hair, J. F., Black, W. C., Babin, J. B., \& Anderson, R. E. (2010). Multivariate Data Analysis. (7th ed.). Upper Saddle River, NJ: Prentice Hall

Haneef, M.A., Pramanik, A.H., Mohammed, M.O., Fouad, M. Bin Amin., \& Muhammad, A.D. (2014). Integrated Waqf Based Islamic Microfinance Model (IWIMM ) for Poverty Alleviation in OIC Member Countries. Middle East Jounal of Scientific Research, 19(2).

Hasan, S. (2006). Muslim Philanthropy and Social Security: Prospects, Practices, and Pitfalls. Paper presented at The $6^{\text {th }}$ ISTR Biennial Conference, Bangkok.

Hoe, S.L., (2008). Issues and Procedure in Adopting Structural Equation Modeling Technique. Journal of Applied Quantitative Methods, 3(1), 76-83.

Indrawati, N.K. (2014). Management by Inspiration: Implementation of Transformational Leadership on Business at Pondok Pesantren Sunan Drajat. Procedia - Social and Behavioral Sciences, 115.

Isbah, M.F. (2016). Examining the Socio-Economic Role of Islamic Boarding Schools (Pesantren) in Indonesia (Doctoral Thesis). School of Humanities and Social Sciences UNSW, Canberra, Australia

Kahf, M. (1998). Financing Development of Awqaf Property. Paper presented at Seminar on Development of Awqaf, Kuala Lumpur. 
Kamri, N.A. (2010). The Roles of Ethics in Waqf Management: Case of Jawhar. Shariah Journal, 18(3).

Khan, M.T. (2015). Development of Human Capital Through Institution of Islamic Waqf. International Journal of Information, Business and Management, 7(3).

Mannan, M. A. (2005). The Role of Waqf in Improving the Ummah Welfare. Paper presented at The International Seminar on Islamic Economics as Solution, Jakarta.

Mohsin, M.I.A. (2013). Financing through Cash-Waqf: A Revitalization to Finance Different Needs. International Journal of Islamic and Middle Eastern Finance and Management 6(4).

Parkin, M. (2016). Economics (12th ed.). London: Pearson Education.

Phillips, L. W., Chang, D. R., \& Buzzell, R. D. (1983). Product Quality, Cost Position and Business Performance: A Test of Some Key Hypotheses. Journal of Marketing, 47(2), 26-43.

Poulsson, S.H.G. \& Kale, S.H. (2004). The Experience Economy and Commercial Experiences. The Marketing Review, 4, 267-277.

$$
\text { قحف, منذر .(2000). الوقف الإسلامي، تطوره، إدارنه، تتميته. دمثق: دار الفكر المعاصر. }
$$

Rashid, S.K. (2012). Measures for the Better Management of Awqaf. International Isalmic University Malaysia Law Journal, 20(1).

Safrina, N, Soehartono, A. \& Setiawan, B. (2017). Studi Literatur: Inkoporasi Keuangan Komersial Dan Sosial Islam Untuk Meningkatkan Konsistensi Sistem Keuangan Islam. Jurnal Intekna.

Shulthoni, M. (2018). Waqf Fundraising Management: A Proposal for A Sustainable Finance of The Waqf Institutions. Journal of Islamic Monetary Economics and Finance (Special Issues). 3.

Siswanto, et al. (2013). Entrepreneurial Motivation in Pondok Pesantren. International Journal of Business and Behavioral Sciences, 3(2).

Stahl, K. (1987). Theories of Urban Business Locaation, In E.S. Mills (Ed.), Handbook of Regional and Urban Economics, Vol. II (759-820). Elsevier Science Publishers B.V.

Suhaimi, F.M., Rahman, A.A., \& Marican, S. (2014). The Role of Share Waqf in The Socio-Economic Development of The Muslim Community: The Malaysian Experience. Humanomics, 30(3).

Thaker, M.A. (2018). A Qualitative Inquiry into Cash Waqf Model As a Source of Financing for Micro Enterprises. ISRA International Journal of Islamic Finance, 10(1).

Umam, K. (2018). Lecture Notes, International Center for Awqaf Studies, University of Darussalam Gontor Indonesia.

Wijayanto, S.H. (2015). Metode Penelitian Menggunakan Structural Equation Modeling dengan Lisrel 9. Jakarta: Lembaga Penerbit Fakultas Ekonomi UI.

Zuki, M.S.Md. (2012). Waqf and Its Role in Socio-Economic Development. ISRA International Journal of Islamic Finance, 4(2). 